\title{
Bireylerin Akılcı İlaç Kullanım Bilgi Düzeylerinin İncelenmesi
}

\author{
Mustafa MACIT* ${ }^{*}$ Mesut KARAMAN**, Mesut PARLAK ${ }^{* * *}$
}

Öz

Tanımlayıcı nitelikteki bu araștırma Kahramanmaraș Göksun ilçesinde hastaların akılcı ilaç kullanım bilgi düzeylerini ve davranıșlarını belirlemek amacıyla yapılmıștır. Araştırmada T.C. Sağlık Bakanlığı tarafından oluşturulan "Akılcı İlaç Kullanımı” ölçeği kullanılmıștır. Araștırmaya 173 katılımcı katkıda bulunmuşlardır. Veriler SPSS 21 paket programıyla analiz edilmiş ve sayl-yüzdelik hesaplama, ki-kare testlerinden yararlanılmıștır. Katılımcıların \% 69,9'u erkek (n=121), \% 30,1'i kadın (n=52) olup yaşlarının dağılımında ise \%38,2 18-30 yaș arası, \% 32,9'u 21-40 yaş arası \%19,1'i 41-50 yaş arası ve \%9,8'i 51-64 yaş arasıdır. Sonuç olarak erkek katılımcıların \%49,2'sinin kadın katılımcıların ise \%46,2'sinin reçete ile eczaneden ağrı kesici aldığı görülmüștür. Katılımcıların cinsiyetleri ile ağrı kesici temin etme durumları arasında anlamlı bir farklılık olduğu belirlenmiştir $(\mathrm{p}<0,05)$. Bireylerin \%94,2'sinin daha önce kullanmıș olduğu ilaç hakkında veya kronik rahatsızlı̆̆ı varsa hekimi veya ilgili sağlık personelini bilgilendirirken, katılımcların gelir seviyesi ve eğitim durumlarıyla bilgilendirme durumları arasında istatistiksel olarak anlamlı bir farklılık bulunmuştur $(p<0,05)$. Çalışma sonunda katılımcıların akılcı ilaç kullanım bilgi düzeyleri yüksek olduğu ve bu bulgunun literatür ile uyumlu olduğu görülmüştür.

Anahtar Kelimeler: Birey, Toplum, Bilgi, İlaçlar, Akılcı İlaç Kullanımı, Akılcı Olmayan İlaç Kullanımı.

\section{Investigation of Individuals' Rational Drug Use Knowledge Levels}

\section{Abstract}

This descriptive study was conducted to determine the rational drug use levels and behaviors of the patients in Kahramanmaras Göksun province. T.C. The "Rational

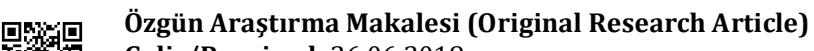 \\ Geliș/Received: 26.06 .2018 \\ Kabul/Accepted: 04.07.2019 \\ DOI: http://dx.doi.org/10.17336/igusbd.435164}

* Dr. Öğr. Üyesi, Kahramanmaraş Sütçü İmam Üniversitesi, İktisadi ve İdari Bilimler Fakültesi, Sağlı Yönetimi Anabilim Dalı, Kahramanmaraş, Türkiye, E-posta: mustafamacit@ksu.edu.tr ORCID ID https://orcid.org/0000-0002-5672-5161

${ }^{* *}$ Yüksek Lisans Öğrencisi, Kahramanmaraş Sütçü İmam Üniversitesi, Sosyal Bilimler Enstitüsü, Sağlık Yönetimi Anabilim Dalı, Kahramanmaraş, Türkiye, E-posta: mesut karaman66@ hotmail.com ORCID ID https://orcid.org/0000-0001-6154-8940

*** Yüksek Lisans Öğrencisi, Kahramanmaraş Sütçü İmam Üniversitesi, Sosyal Bilimler Enstitüsü, Sağlık Yönetimi Anabilim Dalı, Kahramanmaraş, Türkiye, E-posta: mesutparlakk@hotmail.com ORCID ID https://orcid.org/0000-0002-3550-1425 
Drug Use" scale established by the Ministry of Health was used. 173 participants contributed to the survey. The data were analyzed with the SPSS 21 packet program and the number-percentage calculations were made using chi-square tests. $69.9 \%$ of the participants were male $(n=121), 30.1 \%$ were female $(n=52)$ and $38.2 \%$ were in the distribution of their ages between 18 and 30 years, $32,9 \%$ were between 21 and 40 years $19,1 \%$ between the ages of $41-50$ and $9.8 \%$ between the ages of $51-64$. As a result, it was seen that $49.2 \%$ of male participants and $46.2 \%$ of female participants received prescription medication from the pharmacy. It was determined that there was a significant difference between the sex of the participants and the availability of pain relievers $(p<0.05)$. A statistically significant difference was found between the level of income of the participants and the level of informed education $(p<0,05)$, while $94.2 \%$ of the individuals informed the physician or related health personnel about the drug they had used before or if they had a chronic illness. At the end of the study, participants' rational drug use knowledge levels were found to be high and this bullet was found to be compatible with the literature.

Keywords: Individual, Society, Knowledge, Drugs, Rational Drug Use, NonRational Drug Use.

\section{Giriş}

Akılcı ilaç kullanımı hastaya doğru teşhisin konmasından başlayıp, hastanın rahatsızlığı ve özelliklerine göre en etkin tedavi yönteminin seçilmesi, uygulanması, tedavi sonuçlarının izlenmesi ve değerlendirilmesini içeren bütüncül bir yaklaşımdır (WHO, 1997; Ekenler \& Koçoğlu, 2016, s. 45). Dünya sağlık örgütü akılcı ilaç kullanımını "bireylerin klinik bulgularına ve bireysel özelliklerine göre uygun ilacın uygun süre ve dozda, en düşük maliyetle ve kolayca sağlanabilmesi" olarak tanımlamıștır. (WHO, 1985; Yılmaz, Kırbıyıkoğlu, İltuş, Ariç, \& Kurşun,2014, s. 40). Akılcı ilaç kullanımı bütün ülkelerin ulaşmak istediği bir amaçtır ve Dünya Sağlık Örgütü de bu konuda önemli çalıșmalar yaparak, bu amacın gerçekleștirilmesini sağlamak istemektedir (WHO, 2011, s.1).

Akılcı ilaç kullanımı ilaç yönetiminin akılcılığı, ilaç bilgisi desteğinin, reçete yanıtlama sürecinin akılcılığı, reçete yazma sürecinin akılcılığı, ilaç lojistiğinin akılcılığı, ilaçların akılcı seçimi ve ilaçların akılcı tüketimi gibi birtakım unsurlardan oluşmaktadır (Ekenler \& Koçoğlu, 2016, s. 45-46). Akılcı ilaç kullanımı hekim tarafından belirlenen ilacın, doğru miktarda, belirlenen uygulama yöntemleriyle, hekimin önerdiği zamanlarda, uygulanan ilaçlar hakkında yeterli bilgilendirme yapılarak, maliyet uygunluğu da dikkate alınarak kullanılması ilkelerinin bütünü olarak ifade edilebilir (Akıcı \& Kalaça, 2013, s. 5). Akılcı ilaç kullanımının üç ana ögesi bulunmaktadır. Bunlardan ilki arz öğesi (hekimler, eczacılar, ilaç endüstrisi) ikincisi talep öğesi (tüketiciler / toplum (hastalar)) son olarak ise, düzenleyici ve denetleyici mekanizmalar (devlet, sivil toplum kuruluşları ve geri ödeme kurumu) gelmektedir (Sürmelioğlu, Kıroğlu, Erdoğdu, \& Karataş, 2015, s. 454).

Akılcı ilaç kullanımında hekim hastaya tedavi için alması gereken ilaçları reçete ettiğinde eczane personelinin ilaçların kullanımını hastanın anlamasını sağlayacak şekilde anlayıncaya kadar bilgilendirmesi gerekmektedir. Bu konu da en önemli sorumluluk eczane görevlisine düşmektedir. Hastaya konulan teșhiste ileri derece bir hastalı̆̆ı varsa tedavinin tüm süreci boyunca kullanacağı tüm ilaçları hekimin bilgilendirme yapması ve hastayı bütün süreç boyunca izlemesi gerekmektedir. Akılcı ilaç kullanımı dışında kalan diğer uygulamalar akılcı olmayan ilaç kullanımı olarak değerlendirmektedir. Akılcı olmayan ilaç kullanımlarında eczanede satılan pek çok ilacın 
reçetesiz olarak alınabilmesi ve bireylerin kendi başına eczaneden ilaç alıp hekim tavsiyesi olmadan kendilerini tedavi etmeyi istemeleri gelmektedir (Yapıcı, Balıkçı, \& Uğur 2011, s.459).

Akılcı olmayan ilaç kullanımı tedavinin etkisinin azalması, artan hastalıklar, ölüm, tedavi maliyetinin artması, ilaç yan etkileri gibi risklerle hasta için istenmeyen sonuçlara ve kıt kaynakların verimsiz kullanımına sebebiyet vermektedir (Afriyie \& Tetteh, 2014, s. 142). Akılcı olmayan ilaç kullanımlarına bireylerde hastaların reçetesiz ilaç kullanımı, hekimlerin önerdikleri ilaçları düzenli kullanmamaları ve tedavi süreçlerini aksatmaları örnek olarak verilebilir. Akılcı olmayan ilaç kullanımlarında tedavi başarısının azalması, hastaların iyileșme yönündeki ümitlerinin azalması hastanın tedavi süreci içerisindeki göstereceği uyumu da azaltmaktadır (Toprak, 2013; Gündoğar, Soykut, \& Kartal, 2017, s.27).

Bireylerin hastalık durumlarında bilinçsiz bir şekilde ilaç kullanması hem kendi sağlığını olumsuz yönde etkilerken, hem de maddi olarak zarara ve ilaç stoklarında azalmalara neden olmaktadır. Bu zarar ve kayıpları engelleyebilmek için öncelikli olarak bireylerin ve toplumun kendi sağlığının değerini bilmeli ve sağlıklı yaşam biçimini tercih etmeli ve bunu yaşam boyu kalıcı hale getirmelidir. Arzu edilmemesine rağmen herhangi bir hastalık halinde de hekim bilgisi ve yönlendirmeleri dışında ilaç kullanılmamalıdır.

\section{Yöntem}

Tanımlayıcı tipteki bu araștırma bireylerin akılcı ilaç kullanımı bilgi düzeylerinin ve davranışlarının belirlenmesi amacıyla Kahramanmaraş Göksun ilçesinde ilaç almak amacıyla eczanelere gelen hastalar üzerinde yapılmıştır. Araștırma evrenini Kahramanmaraş Göksun ilçesindeki eczanelere hizmet almaya gelen tüm hastalar oluşturmaktadır. Araştırmanın yapıldığı dönemde Göksun'da yedi eczane bulunmaktadır. Araştırma örneklemi ise Ocak-Nisan 2018 tarihleri arasında bu eczanelerden beş tanesine hizmet almaya gelen bireyler oluştururken, olasılıksız gelișigüzel örneklem yöntemiyle 173 hastaya ulaşılmıștır. Anket uygulamandan önce muhtemel katılımcılara anket hakkında bilgi verilmiş ve bireylerin rızası alınarak anket uygulanmıştır. Veriler gelen hastalardan birebir görüşme yoluyla toplanmıștır.

Verilerin toplanmasında Sağlık Bakanlığı tarafından geliştirilen bireylerin akılcı ilaç kullanımı bilgi düzeylerini belirlemeye yönelik anket kullanılmış ve bazı ilave bilgilerin elde edilmesi amacıyla araștırmacılar tarafından ölçeğe ilave sorular eklenmiștir. Verilerin analizinde SPSS 21 programından faydalanılmıș, frekans, sayıyüzde hesaplama ve gruplar arası farklılığı belirlemede ki-kare analizinden yararlanılmıștır. Araștırma grubunda bağımsız değișkenler katılımcıların sosyodemografik özellikleri (yaş, cinsiyet, gelir durumu, eğitim durumu ve meslek dağılımı) oluşturmaktadır. Bağımlı değiş̧keni ise bireylerin akılcı ilaç kullanımıdır.

\section{Bulgular ve Tartışma}

Katılımcıların sosyo-demografik özellikleri Tablo 1'de verilmiştir. Katılımcıların \% 69,9'u erkek (n=121), \% 30,1'i kadın ( $n=52$ ) olup, \%38,2'si 18-30 yaș arası, \% 32,9'u 2140 yaş arası \%19,1'i 41-50 yaş arası ve \%9,8'i 51-64 yaş arasındadır. Katılımcıların \% 34,1 'i lisans mezunu, \% 32,9'u lise mezunu, \%20,8'i ise yüksek lisans/doktora mezunudur. 
Tablo 1: Katılımcıların Sosyo-Demografik Özellikleri

\begin{tabular}{|l|l|l|}
\hline $\begin{array}{l}\text { Demografik } \\
\text { Değișkenler }\end{array}$ & $\mathbf{N}$ & $\mathbf{\%}$ \\
\hline Cinsiyet & & \\
\hline Kadın & 52 & 30,1 \\
\hline Erkek & 121 & 69,9 \\
\hline Yaș & & \\
\hline 18-30 yaș arası & 66 & 38,2 \\
\hline 21-40 yaș arası & 57 & 32,9 \\
\hline $41-50$ yaș arası & 33 & 19,1 \\
\hline 51-64 yaș arası & 17 & 9,8 \\
\hline Eğitim durumu & & \\
\hline Illköğretim & 21 & 12,1 \\
\hline Lise & 57 & 32,9 \\
\hline Lisans & 59 & 34,1 \\
\hline $\begin{array}{l}\text { Yüksek } \\
\text { lisans/doktora }\end{array}$ & 36 & 20,8 \\
\hline Gelir seviyesi & & \\
\hline $0-499$ TL & 19 & 11,0 \\
\hline $500-999$ TL & 6 & 3,5 \\
\hline $1000-1499$ TL & 19 & 11,0 \\
\hline $1500-1999$ TL & 35 & 20,2 \\
\hline 2000 TL ve üzeri & 94 & 54,3 \\
\hline Meslek & & \\
\hline Ev hanımı & 8 & 4,6 \\
\hline Öğrenci & 21 & 12,1 \\
\hline Isş̧i & 49 & 28,3 \\
\hline Memur & 51 & 25,4 \\
\hline Serbest meslek & 44 & \\
\hline
\end{tabular}

Katılımcıların \% 54,3'ü 2000 TL ve üzeri geliri olduğunu, \% 20,2'si 1500-1999 TL arası geliri olduğunu \%11'i ise 1000-1499 TL ve \%11'i 0-499 TL arası geliri olduğunu belirmiștir. Katılımcıların \%29,5'inin memur, \% 28,3'ünün iş̧̧i, \%25,4 'ünün serbest meslek \%12,1'inin öğrenci ve \%4,6'sının ev hanımı olduğu görülmektedir.

Tablo 2'de bireylerin cinsiyetleri ile akılcı ilaç kullanımı özellikleri gösterilmektedir. Yapılan analiz sonucu bireylerin ağrı kesici ihtiyaçları olduğunda temin etme yöntemleri ile cinsiyetleri arasında istatistiksel açıdan anlamlı bir farklılık olduğu görülmektedir ( $\mathrm{p}<0,05)$. Erkek bireylerin \%49,6'sı ağrı kesici ihtiyaçları olduğunda reçete ile eczaneden aldıklarını belirtirken, kadın katılımclların ise \%46,2'si reçete ile eczaneden ağrı kesici temin ettiklerini ifade etmişlerdir. 
Tablo 2: Bireylerin Cinsiyetleri İle Akılcı İlaç Kullanımı Özellikleri

\begin{tabular}{|c|c|c|c|c|c|c|c|}
\hline \multicolumn{8}{|c|}{ Ağrı kesici ihtiyacınız olduğunda ilacı nasıl temin edersiniz? } \\
\hline \multirow[b]{2}{*}{ Cinsiyet } & \multicolumn{2}{|c|}{$\begin{array}{l}\text { Reçete İle } \\
\text { Eczaneden }\end{array}$} & \multicolumn{2}{|c|}{$\begin{array}{l}\text { Reçetesiz } \\
\text { Eczaneden }\end{array}$} & \multicolumn{2}{|c|}{$\begin{array}{l}\text { Komşudan } \\
\text { Tanıdıktan }\end{array}$} & $\begin{array}{l}\text { Test ve p } \\
\text { değeri }\end{array}$ \\
\hline & $\mathrm{N}$ & $\%$ & $\mathrm{~N}$ & $\%$ & $\mathrm{~N}$ & $\%$ & \multirow{3}{*}{$\begin{array}{l}\chi^{2}: 7,161 \\
\text { P:0,028* }\end{array}$} \\
\hline Kadın & 24 & 46,2 & 19 & 36,2 & 9 & 17,3 & \\
\hline Erkek & 60 & 49,6 & 55 & 45,5 & 6 & 5,0 & \\
\hline \multicolumn{8}{|c|}{ Hastalık durumunda ne yaparsınız? } \\
\hline & \multicolumn{2}{|c|}{$\begin{array}{l}\text { Hekime } \\
\text { Danışırım }\end{array}$} & \multicolumn{2}{|c|}{$\begin{array}{l}\text { Eczacıya } \\
\text { Danıșırım }\end{array}$} & \multicolumn{2}{|c|}{$\begin{array}{l}\text { Bitkisel } \\
\text { Tedavi }\end{array}$} & $\begin{array}{l}\text { Test ve p } \\
\text { değeri }\end{array}$ \\
\hline Cinsiyet & $\mathrm{N}$ & $\%$ & $\mathrm{~N}$ & $\%$ & $\mathrm{~N}$ & $\%$ & \multirow{3}{*}{$\begin{array}{l}\chi^{2}: 6,974 \\
\text { P:0,031* }\end{array}$} \\
\hline Kadın & 43 & 82,7 & 8 & 15,4 & 1 & 1,9 & \\
\hline Erkek & 111 & 91,7 & 5 & 4,1 & 5 & 4,1 & \\
\hline \multicolumn{8}{|c|}{ İlacın son kullanma tarihini kontrol eder misiniz? } \\
\hline & \multicolumn{2}{|c|}{ Daima } & \multicolumn{2}{|c|}{ Genellikle } & \multicolumn{2}{|c|}{ Bazen } & $\begin{array}{l}\text { Test ve p } \\
\text { değeri }\end{array}$ \\
\hline Cinsiyet & $\mathrm{N}$ & $\%$ & $\mathrm{~N}$ & $\%$ & $\mathrm{~N}$ & $\%$ & \multirow{3}{*}{$\begin{array}{l}\chi^{2}: 6,702 \\
\text { P:0,038* }\end{array}$} \\
\hline Kadın & 30 & 57,7 & 11 & 21,2 & 11 & 21,2 & \\
\hline Erkek & 81 & 66,9 & 31 & 25,6 & 9 & 7,4 & \\
\hline
\end{tabular}

Satır yüzdesi alınmıştır. ${ }^{*} P<0,05$

Yine Tablo 2'den görülebileceği gibi katılımcıların hastalık durumundaki yönelimleri ile cinsiyetleri arasında istatistiksel açıdan anlamlı bir farklılık saptanmıștır ( $\mathrm{p}<0,05)$. Erkek katılımcların oransal olarak \%91,1'i ve kadın katılımcıların \%82,7'sinin hekime danıştıklarını belirtmişlerdir. Araștırma katılımcılarının aldıkları ilacın son kullanma tarihini kontrol etme durumları ile cinsiyetleri arasında istatiksel olarak anlamlı bir farklılık olduğu görülmektedir ( $\mathrm{p}<0,05)$. Erkek katılımcıların \%66,9’u aldıkları ilacın son kullanma tarihini daima kontrol ettiği bulgulanırken, kadın katılımcılarda ise bu oran $\% 57,7^{\prime}$ dir

Tablo 3'te katılımcıların cinsiyet ve eğitim durumları ile akılcı ilaç kullanımına yönelik özellikleri verilmiştir. Bireylerin evde bulundurdukları ilaçları tekrar kullanmak istediklerinde kimden bilgi alırsınız sorusuna verdikleri yanıtları ile sırasıyla cinsiyetleri (p: 0,012) ve eğitim durumları (p:0,006) arasında istatistiksel açıdan anlamlı bir farklılık olduğu belirlenmiştir $(\mathrm{p}<0,05)$. Erkek katılımcıların \%41,3'ü hekimden bilgi aldıklarını, $\% 28,1$ 'i ise eczane görevlisinden bilgi aldıklarını belirtirken, kadın katılımclların \%32,7'sinin ise hekimden bilgi aldıkları görülmüştür. Eğitim durumu dikkate alındığında yükseköğretim mezunlarının \% 39'u ve yüksek lisans/doktora mezunlarının \%41,9'u hekimden bilgi aldıklarını, lise mezunlarının \%40,4'ü eczacı personelinden bilgi aldıklarını, ilköğretim mezunlarının \% 57,1'inin hekimden bilgi aldıkları bulgusuna ulaşılmıştır. 
Tablo 3: Katılımcıların Cinsiyet ve Eğitim Durumlarına Göre Akılcı İlaç Kullanım Özellikleri

\begin{tabular}{|c|c|c|c|c|c|c|c|c|c|}
\hline \multicolumn{10}{|c|}{ Evde bulundurmuş olduğunuz ilaçları tekrar kullanmak istediğinizde kimden bilgi alırsınız? } \\
\hline & \multicolumn{2}{|c|}{ Hekim } & \multicolumn{2}{|c|}{ Eczacı } & \multicolumn{2}{|c|}{$\begin{array}{l}\text { Hemşire } \\
\text { veya sağlık } \\
\text { görevlisi }\end{array}$} & \multicolumn{2}{|c|}{$\begin{array}{lr}\begin{array}{l}\text { Daha } \\
\text { kullandığım }\end{array} & \begin{array}{r}\text { önce } \\
\text { için } \\
\text { kimseden } \\
\text { bilgi } \\
\text { almam }\end{array} \\
\end{array}$} & $\begin{array}{l}\text { Test ve p } \\
\text { değeri }\end{array}$ \\
\hline Cinsiyet & $\mathrm{N}$ & $\%$ & $\mathrm{~N}$ & $\%$ & $\mathrm{~N}$ & $\%$ & $\mathrm{~N}$ & $\%$ & \multirow{3}{*}{$\begin{array}{l}\chi^{2}: 10,990 \\
\text { P:0,012* }\end{array}$} \\
\hline Kadın & 17 & 32,7 & 16 & 30,8 & 8 & 15,4 & 11 & 21,2 & \\
\hline Erkek & 50 & 41,3 & 34 & 28,1 & 3 & 2,5 & 34 & 28,1 & \\
\hline \multicolumn{9}{|l|}{ Eğitim durumu } & \multirow{5}{*}{$\begin{array}{l}\chi^{2}: 22,881 \\
\mathbf{p}: 0,006^{*}\end{array}$} \\
\hline İlköğretim & 12 & 57,1 & 9 & 42,9 & 0 & 0 & 0 & 0 & \\
\hline Lise & 17 & 29,8 & 23 & 40,4 & 4 & 7,0 & 13 & 22,8 & \\
\hline Yükseköğretim & 23 & 39,0 & 10 & 16,9 & 3 & 5,1 & 23 & 39,0 & \\
\hline $\begin{array}{l}\text { Yüksek } \\
\text { lisans/doktora }\end{array}$ & 15 & 41,7 & 8 & 22,2 & 4 & 11,1 & 9 & 25,0 & \\
\hline \multicolumn{10}{|c|}{ Evinizde hiç kullanılmamış veya yarım kalmış ortalama kaç kutu ilaç vardır? } \\
\hline & \multicolumn{2}{|c|}{ Hiç Yok } & \multicolumn{2}{|c|}{ 1-5 arası } & \multicolumn{2}{|c|}{ 6-10 arası } & \multicolumn{2}{|c|}{ 10'dan fazla } & \multirow{4}{*}{$\begin{array}{l}\chi^{2}: 9,115 \\
\text { P:0,028* }\end{array}$} \\
\hline Cinsiyet & $\mathrm{N}$ & $\%$ & $\mathrm{~N}$ & $\%$ & $\mathrm{~N}$ & $\%$ & $\mathrm{~N}$ & $\%$ & \\
\hline Kadın & 12 & 23,1 & 16 & 30,8 & 8 & 15,4 & 16 & 30,8 & \\
\hline Erkek & 34 & 28,1 & 57 & 47,1 & 14 & 11,6 & 16 & 13,2 & \\
\hline \multicolumn{9}{|l|}{ Eğitim durumu } & \multirow{5}{*}{$\begin{array}{l}\chi^{2}: 21,756 \\
\mathbf{p}: \mathbf{0 , 0 1 0 *}\end{array}$} \\
\hline İlköğretim & 9 & 42,9 & 9 & 42,9 & 3 & 14,3 & 0 & 0 & \\
\hline Lise & 15 & 26,3 & 27 & 47,4 & 7 & 12,3 & 8 & 14,0 & \\
\hline Yükseköğretim & 16 & 27,1 & 24 & 40,7 & 10 & 16,9 & 9 & 15,3 & \\
\hline $\begin{array}{l}\text { Yüksek } \\
\text { lisans/doktora }\end{array}$ & 6 & 16,7 & 13 & 36,1 & 2 & 5,6 & 15 & 41,7 & \\
\hline
\end{tabular}

Satır yüzdesi alınmıştır. ${ }^{*} P<0,05$

Yine Tablo 3'ten görülebileceği gibi bireylerin evlerinde hiç kullanılmamış veya yarım kalmış olan ilaç kutu miktarında erkek bireylerin \%47,1'i ile kadın bireylerin \%30,8'i 1-5 kutu arası ilaç bunduğunu belirtmiștir. Katılımcıların cinsiyetleri ile evlerinde hiç kullanılmamış veya yarım kalmış olan ilaç bulundurma durumları ile arasında istatiksel olarak anlamlı bir farklılık olduğu görülmüştür $(\mathrm{p}<0,05)$.

Tablo 3'te görülebileceği gibi eğitim durumu açısından incelendiğinde yükseköğretim mezunlarının \% 40,7'si, lise mezunlarının \% 47,4'ü evlerinde 1-5 kutu arası ilaç bulunduğunu ifade ederken, yüksek lisans/doktora mezunlarının \%41,5'inin 10 'dan fazla ilaç bulundurmakta oldukları bulgulanmıştır. Katılımcıların eğitim durumları ile evlerinde hiç kullanılmamış veya yarım kalmış olan ilaç kutu bulunma durumları arasında istatiksel olarak incelendiğinde anlamlı bir farklılık olduğu görülmektedir $(\mathrm{p}<0,05)$.

Tablo 4'te katılımcıların demografik özellikleriyle akılcı ilaç bilgi ve kullanım düzeyleri arasındaki ilişkiyi gösteren analiz sonuçları verilmiştir. Tablo 4 incelendiğinde eczane görevlisinin alınan ilaçların nasıl kullanılacağı konusunda bilgi verip doğru anlaşıldığına emin olana kadar anlatma durumları ile katılımcıların cinsiyetleri arasında anlamlı bir farklılık bulunmuștur $(\mathrm{p}<0,05)$. Erkek katılımclların \% 95'i kadın katılımcıların ise \% 84,6'sı eczane personelinin alınan ilaçların nasıl kullanılacağı konusunda bilgi verip, doğru anlaşıldığına emin olana kadar anlattıklarını belirtmişlerdir.

Tablo 4'te görülebileceği gibi "Sizce ilaçların uygulama șekli tedavi başarısına etkili midir ?" sorusu ile katılımcların sırasıyla cinsiyetleri ve eğitim durumları arasında istatiksel açıdan anlamlı bir farklılık bulunmuştur ( $\mathrm{p}<0,05)$. Erkek katılımcıların \% 84,3'ü ile kadın katılımcıların \% 67,3'ü "Evet, enjektabl (iğne) olursa daha iyi tedavi olurum" yanıtını vermişlerdir. Eğitim durumları açısından incelendiğinde lise mezunlarının \% 87,7'sinin, ilköğretim mezunlarının \% 85,7'sinin, yükseköğretim mezunlarının 
\%79,7'sinin ve yüksek lisans/doktora mezunlarının \% 61,1'i “Evet, enjektabl (iğne) olursa daha iyi tedavi olurum" yanıtını verdikleri görülmektedir.

Yine Tablo 4'te bireylerin besin veya ilaç alerjiniz var ise; muayene sırasında hekimi ve ilgili sağlık personelini bilgilendirme durumlarıyla sırasıyla yaş ve eğitim durumları arasında istatiksel olarak anlamlı bir farklılık olduğu görülmektedir $(\mathrm{p}<0,05)$. Katılımcıların 51-64 yaș arası grubun tamamı, 41-50 yaş arasının \% 90,9'u, 31-40 yaş arası grubun \%98,2'si, 18-30 yaş arası grubun ise \% 84,8'i besin veya ilaç alerjisi var ise; muayene sırasında hekimi ve ilgili sağllk personelini bilgilendirmektedirler (Bkz. Tablo 4). Aynı soru bireylerin eğitim durumları açısından değerlendirildiğinde, yükseköğretim mezunlarının \% 96,6'sının, ilköğretim mezunlarının \% 95,2'sinin, lise mezunlarının \%93'ünün, yüksek lisans/doktora mezunlarının ise 80,4'ünün besin veya ilaç alerjisi konusunda hekim ve ilgili sağlık personelini bilgilendirdikleri bulgusuna ulaşılmıştır.

Tablo 4: Demografik Değişkenlere Göre Akılcı İlaç Kullanım Özellikleri

\begin{tabular}{|c|c|c|c|c|c|}
\hline \multicolumn{6}{|c|}{$\begin{array}{l}\text { Eczacınız, aldığınız ilacın nasıl kullanılacağı konusunda bilgi verip doğru anlaşıldığına emin olana } \\
\text { kadar anlatıyor mu? }\end{array}$} \\
\hline \multirow[b]{2}{*}{ Cinsiyet } & \multicolumn{2}{|c|}{ Evet } & \multicolumn{2}{|c|}{ Hayır } & $\begin{array}{l}\text { Test ve p } \\
\text { değeri }\end{array}$ \\
\hline & $\mathrm{N}$ & $\%$ & $\mathrm{~N}$ & $\%$ & \multirow{3}{*}{$\begin{array}{l}\chi^{2}: 5,315 \\
\mathbf{P}: \mathbf{0 , 0 3 2} *\end{array}$} \\
\hline Kadın & 44 & 84,6 & 8 & 15,4 & \\
\hline Erkek & 115 & 95,0 & 6 & 5,0 & \\
\hline \multicolumn{6}{|c|}{ Sizce ilaçların uygulama șekli tedavi bașarısına etkili midir? } \\
\hline & \multicolumn{2}{|c|}{$\begin{array}{l}\text { Evet, enjektabl (iğne) olursa } \\
\text { daha iyi tedavi olurum }\end{array}$} & \multicolumn{2}{|c|}{$\begin{array}{l}\text { İğneden korkarım, ağıdan } \\
\text { alınan ilaçları tercih ederim }\end{array}$} & \multirow{4}{*}{$\begin{array}{l}\chi^{2}: 6,371 \\
\mathbf{P}: 0,012 *\end{array}$} \\
\hline Cinsiyet & $\mathrm{N}$ & $\%$ & $\mathrm{~N}$ & $\%$ & \\
\hline Kadın & 35 & 67,3 & 17 & 32,7 & \\
\hline Erkek & 102 & 84,3 & 19 & 15,7 & \\
\hline \multicolumn{5}{|l|}{ Eğitim durumu } & \multirow{5}{*}{$\begin{array}{l}\chi^{2}: 10,207 \\
\mathbf{p}: \mathbf{0 , 0 1 7}\end{array}$} \\
\hline İlköğretim & 18 & 85,7 & 3 & 14,3 & \\
\hline Lise & 50 & 87,7 & 7 & 12,3 & \\
\hline Yükseköğretim & 47 & 79,7 & 12 & 20,3 & \\
\hline $\begin{array}{l}\text { Yüksek } \\
\text { lisans/doktora }\end{array}$ & 22 & 61,1 & 14 & 38,9 & \\
\hline \multicolumn{6}{|c|}{$\begin{array}{l}\text { Besin veya ilaç alerjiniz var ise; muayene sırasında hekimi ve ilgili sağlık personelini bilgilendirir } \\
\text { misiniz? }\end{array}$} \\
\hline & \multicolumn{2}{|c|}{ Evet, bilgilendiririm } & \multicolumn{2}{|c|}{ Sorarsa bilgilen diririm } & \multirow{6}{*}{$\begin{array}{l}\chi^{2}: 9,042 \\
\text { P:0,025* }\end{array}$} \\
\hline Yaș & $\mathrm{N}$ & $\%$ & $\mathrm{~N}$ & $\%$ & \\
\hline 18-30 yaș arası & 56 & 84,8 & 10 & 15,2 & \\
\hline 31-40 yaș arası & 56 & 98,2 & 1 & 1,8 & \\
\hline 41-50 yaș arası & 30 & 90,9 & 3 & 9,1 & \\
\hline 51-64 yaș arası & 17 & 100 & 0 & 0 & \\
\hline \multicolumn{5}{|l|}{ Eğitim durumu } & \multirow{5}{*}{$\begin{array}{l}\chi^{2}: 8,394 \\
\text { P:0,035* }\end{array}$} \\
\hline İlköğretim & 20 & 95,2 & 1 & 4,8 & \\
\hline Lise & 53 & 93,0 & 4 & 7,0 & \\
\hline Yükseköğretim & 57 & 96,6 & 2 & 3,4 & \\
\hline $\begin{array}{l}\text { Yüksek } \\
\text { lisans/doktora }\end{array}$ & 29 & 80,6 & 7 & 19,4 & \\
\hline
\end{tabular}

Satır yüzdesi alınmıştır. ${ }^{*} P<0,05$

Tablo 5'te demografik değişkenler açısından akılcı ilaç kullanım özellikleri ve gruplar arası farklılığı gösteren ki-kare analizi verilmiștir. Katılımcıların cinsiyet, yaș, eğitim durumu, gelir seviyesi ve meslek dağılımı gibi demografik özellikleri ile komşularının ve/veya yakınlarının tavsiyesi ile ilaç kullanma ya da doktorlarından ilaç reçete etme durumları arasında istatiksel açıdan anlamlı bir farklılık bulunmamıştır ( $p>0,05$ ). Erkek katılımcıların \%82,4'ü, kadın katılımcıların ise, \% 80,8'inin komşuları ve/veya yakınlarının tavsiyesi ile ilaç kullanmadıklarını ya da doktorlarından reçete etmelerini istemediklerini belirtmişlerdir. Yaş grubu olarak 51-64 yaş arası katılımcıların 
\% 88,2'sinin, 41-50 yaş arası katılımcıların \%81,8'i, memur olanların \% 90,9'unun, işçi olanların \%75,5'inin komşuları ve/veya yakınlarının tavsiyesi ile ilaç kullanmadıklarını ya da doktorlarından reçete etmelerini istemediklerini ifade etmişlerdir.

Tablo 5’ten görülebileceği gibi katılımcıların yaş, gelir seviyesi ve meslekleriyle benzer șikâyetleri olan tanıdıklarına ilaç tavsiyesinde bulunma durumları arasında istatistiksel olarak anlamlı bir farklılık bulunurken $(p<0,05)$, cinsiyet ve eğitim durumları arasında anlamlı bir farklılık bulunmamıștır ( $p>0,05)$. Erkek katılımcıların \%77,7'si ile kadın katılımcıların \%67,3'ünün, yaş grubu olarak 41-50 yaş arası olanların \% 90,9'u, 5164 yaș arası \%82,4'ünün, 31-40 yaș arası \%73,7'sinin, meslek olarak incelendiğinde işçilerin \%84,3'ünün, serbest meslek olarak çalışanların \% 74,6'sının ilaç tavsiyesinde bulunmadıkları belirlenmiștir.

Tablo 5 incelendiğinde katılımcıların cinsiyet, yaș, eğitim durumu, gelir seviyesi ve meslekleri ile ilaçlar ile birlikte tüketilmemesi gereken yiyecek ve içecekler ile ilgili bilgilendirme yapılması durumları arasında istatistiksel açıdan anlamlı bir farklılık saptanmamıștır $(p>0,05)$. Bilgilendirme yapılma durumlarıyla cinsiyet açısından incelendiğinde erkek katılımcıların \% 66,1'i kadın katılımcıların \%57,7'si; yaş grupları açısından incelendiğinde 51-64 yaş arasındakilerin \%70,6'sl, 41-50 yaş arasının \% 63,6'sının, 31-40 yaş arasındakilerin \%59,6'sı; eğitim durumuna bakıldığında lisans mezunlarının \%71,2'sinin, lise mezunlarının \% 64,9'unun, gelir dağılımına bakıldığında 1500-1999 TL geliri olanların \% 74,3'ünün, 2000 TL geliri olanların \% 63,8'inin, ilaçlar ile birlikte tüketilmemesi gereken yiyecek ve içecekler ile ilgili bilgilendirme yapıldığını ifade etmişlerdir.

Tablo 6'da demografik değișkenlere göre akılcı ilaç kullanım özellikleri ve gruplar arası farklılığı gösteren ki-kare analizi sonuçları verilmiştir. Tablo 6 incelendiğinde bireylerin cinsiyet, yaş, gelir durumu ve meslek dağılımı gibi demografik özellikleriyle ilaç temini sırasında reçetede yazılandan farklı olarak, eczacının önerdiği eşdeğer ilacı kabul etme durumlarıyla istatiksel olarak anlamlı bir farklılık olduğu saptanırken $(\mathrm{p}<0,05)$, eğitim durumları ile ilaç temini sırasında reçetede yazılandan farklı olarak, eczacının önerdiği eşdeğer ilacı kabul etme durumları arasında anlamlı bir farklılık saptanmamıștır ( $p>0,05$ ). Cinsiyet dağılımında erkeklerin \%57,9'unun eczacının önerdiği farklı eşdeğer bir ilacı kabul ederken, kadın katılımcıların \%67,3'ü kabul etmemektedirler. Yaş dağılımı incelendiğinde 18-30 yaş arası katılımclların \%68,2'sinin eşdeğer bir ilacı kabul etmedikleri, 41-50 yaș arası olanların \%60,6'sının kabul ettikleri görülmüștür. Meslek dağılımına bakıldığında serbest meslek çalışanlarının \%54,5'inin kabul etmediği, işçilerin \%61,2'sinin kabul ettiği aşağıdaki tablo 6'da görülmektedir.

Tablo 6'da katılımcıların yaș ve eğitim durumu ile reçete ile ilaç alırken, reçetede yazan ilaç olup olmadığını kontrol etme durumları arasında istatiksel olarak anlamlı bir farklılık bulunurken ( $\mathrm{p}<0,05)$, bu ilişki cinsiyet, gelir durumu ve meslek dağılımı açısından istatiksel olarak anlamlı bir farklılık arz etmemektedir ( $p>0,05)$. Yine Tablo 6'da görülebileceği gibi erkek katılımcıların \% 78,5'inin, kadın katılımcıların \% 69,2'sinin reçetede yazan ilaçları kontrol ettikleri bulgusuna ulaşılmıştır. 41-50 yaş arası olanların \% 90,9'unun, 51-54 yaș arası grubun \%88,2'sinin, 31-40 yaş arası olanların \% 68,4'ünün; eğitim durumları incelendiğinde lisans mezunlarının \% 79,7'sinin lise mezunlarının \% 78,5'inin reçetede yazılan ilaçları kontrol ettikleri ortaya çıkmıştır.

Bireylerin eğitim ve gelir durumları ile hekime giderken daha önce kullanmış oldukları ilaçlar veya varsa kronik hastalıklarına ait raporları hakkında hekimi bilgilendirme durumları arasında istatiksel olarak anlamlı bir farklılık olduğu belirlenirken $(\mathrm{p}<0,05)$, cinsiyet, yaş ve meslek dağılımları ile bilgilendirme durumu arasında anlamlı bir farklılık belirlenememiştir $(\mathrm{p}>0,05)$. Hekimi daha önce kullanmış oldukları ilaçlar hakkında veya kronik rahatsızlıkları hakkında bilgilendirme konusunda erkek bireylerin \%86'sının, kadın bireylerin ise \%78,8'inin bilgilendirme yaptıkları 
görülmektedir. Yaş açısından ise 31-40 yaş arası olanların \% 91,2'sinin, 18-30 yaş arası olanların \% 84,8'inin bilgilendirme yaptıkları tespit edilmiştir. Yine Tablo 6'da görülebileceği gibi lise mezunu olanların \%94,'7sinin, lisans mezunu olanların \%86,4'ünün, yüksek lisans mezunu olanların \% 80,6'sının, katılımcıların gelir durumu incelendiğinde 1500-1999 TL geliri olanların \%94,3'ünün, 2000 TL ve üzeri geliri olanların \%85,1'inin daha önce kullanmış oldukları ilaçlar hakkında veya varsa kronik rahatsızlıkları hakkında hekimi bilgilendirdikleri bulgusuna ulaşılmıştır.

Tablo 5: Demografik Değişkenler Açısından Akılcı İlaç Kullanım Özellikleri ve Gruplar Arası Farklılığı Gösteren Ki-Kare Analizi

\begin{tabular}{|c|c|c|c|c|c|c|c|c|c|c|c|c|c|c|c|}
\hline \multirow[b]{3}{*}{ Cinsiyet } & \multicolumn{5}{|c|}{$\begin{array}{l}\text { Komşularınız ve/veya yakınlarınızın tavsiyesi } \\
\text { ile ilaç kullanma ya da doktorunuzdan reçete } \\
\text { etme durumları }\end{array}$} & \multicolumn{5}{|c|}{$\begin{array}{l}\text { Benzer şikâyetleri olan tanıdıklarınıza ilaç } \\
\text { tavsiyesinde bulunma durumları }\end{array}$} & \multicolumn{5}{|c|}{$\begin{array}{l}\text { İlaçlarınızla birlikte tüketilmemesi gereken } \\
\text { yiyecek ve içecekler ile ilgili bilgilendirme } \\
\text { yapılması durumu }\end{array}$} \\
\hline & \multicolumn{2}{|l|}{ Evet } & \multicolumn{2}{|c|}{ Hayır } & \multirow[t]{2}{*}{$\begin{array}{l}\text { Test ve } \\
\text { p değeri }\end{array}$} & \multicolumn{2}{|l|}{ Evet } & \multicolumn{2}{|c|}{ Hayır } & \multirow[t]{2}{*}{$\begin{array}{l}\text { Test ve p } \\
\text { değeri }\end{array}$} & \multicolumn{2}{|l|}{ Evet } & \multicolumn{2}{|c|}{ Hayır } & \multirow[t]{2}{*}{$\begin{array}{l}\text { Test ve } \\
\text { p değeri }\end{array}$} \\
\hline & Say1 & $\%$ & Sayı & $\%$ & & Sayı & $\%$ & Sayı & $\%$ & & Sayı & $\%$ & Say1 & $\%$ & \\
\hline Kadın & 10 & 19,2 & 42 & 80,8 & \multirow{2}{*}{$\begin{array}{l}\chi 2: 0,112 \\
\mathrm{p}: 0,768\end{array}$} & 17 & 32,7 & 35 & 67,3 & \multirow{2}{*}{$\begin{array}{l}\chi^{2}: 2,066 \\
\mathrm{p}: 0,151 \\
\end{array}$} & 30 & 57,7 & 22 & 42,3 & \multirow{2}{*}{$\begin{array}{l}\chi^{2}: 1,114 \\
\mathrm{p}: 0,291\end{array}$} \\
\hline Erkek & 21 & 17,4 & 100 & 82,6 & & 27 & 22,3 & 94 & 77,7 & & 80 & 66,1 & 41 & 33,9 & \\
\hline \multicolumn{16}{|l|}{ Yaș } \\
\hline $\begin{array}{l}18-30 \text { yaș } \\
\text { arası }\end{array}$ & 16 & 24,2 & 50 & 75,8 & \multirow{4}{*}{$\begin{array}{l}\chi^{2}: 1,456 \\
\text { p:0,692 }\end{array}$} & 23 & 34,8 & 43 & 65,2 & \multirow{4}{*}{$\begin{array}{l}\chi^{2: 8,299} \\
\mathbf{p}: \mathbf{0 , 0 4 0 *}\end{array}$} & 43 & 65,2 & 23 & 34,8 & \multirow{4}{*}{$\begin{array}{l}\chi^{2}: 0,811 \\
\mathrm{p}: 0,847\end{array}$} \\
\hline $\begin{array}{l}31-40 \text { yaș } \\
\text { arası }\end{array}$ & 12 & 21,1 & 45 & 78,9 & & 15 & 26,3 & 42 & 73,7 & & 34 & 59,6 & 23 & 40,4 & \\
\hline $\begin{array}{l}41-50 \text { yaș } \\
\text { arası }\end{array}$ & 6 & 18,2 & 27 & 81,8 & & 3 & 9,1 & 30 & 90,9 & & 21 & 63,6 & 12 & 36,4 & \\
\hline $\begin{array}{l}51-64 \text { yaș } \\
\text { arası }\end{array}$ & 2 & 11,8 & 18 & 88,2 & & 3 & 17,6 & 14 & 82,4 & & 12 & 70,6 & 5 & 29,4 & \\
\hline \multicolumn{16}{|l|}{$\begin{array}{l}\text { Eğitim } \\
\text { durumu }\end{array}$} \\
\hline İlköğretim & 5 & 23,8 & 16 & 76,2 & \multirow{4}{*}{$\begin{array}{l}\chi^{2}: 1,176 \\
\mathrm{p}: 0,759\end{array}$} & 4 & 19,0 & 17 & 81,0 & \multirow{4}{*}{$\begin{array}{l}\chi^{2}: 2,337 \\
\mathrm{p}: 0,506\end{array}$} & 13 & 61,9 & 8 & 38,1 & \multirow{4}{*}{$\begin{array}{l}\chi^{2}: 4,41 \\
\mathrm{p}: 0,220\end{array}$} \\
\hline Lise & 14 & 24,6 & 43 & 75,4 & & 17 & 29,8 & 40 & 70,2 & & 37 & 64,9 & 20 & 35,1 & \\
\hline Lisans & 10 & 16,9 & 49 & 83,1 & & 12 & 20,3 & 47 & 79,7 & & 42 & 71,2 & 17 & 28,8 & \\
\hline $\begin{array}{l}\text { Yüksek } \\
\text { lisans/doktora }\end{array}$ & 7 & 19,4 & 29 & 80,6 & & 11 & 30,6 & 25 & 69,4 & & 18 & 50,0 & 18 & 50,0 & \\
\hline \multicolumn{16}{|l|}{$\begin{array}{l}\text { Gelir } \\
\text { seviyesi* }\end{array}$} \\
\hline $0-499 \mathrm{TL}$ & 7 & 36,8 & 12 & 63,2 & \multirow{5}{*}{$\begin{array}{l}\chi^{2}: 5,077 \\
\text { p:0,278 }\end{array}$} & 10 & 52,6 & 9 & 47,4 & \multirow{5}{*}{$\begin{array}{l}\chi^{2}: 9,775 \\
\text { p:0,044* }\end{array}$} & 10 & 52,6 & 9 & 47,4 & \multirow{5}{*}{$\begin{array}{l}\chi^{2}: 3,727 \\
\mathrm{p}: 0,444\end{array}$} \\
\hline $500-999 \mathrm{TL}$ & 0 & 0 & 6 & 100 & & 1 & 16,7 & 5 & 83,3 & & 4 & 66,7 & 2 & 33,3 & \\
\hline $1000-1499 \mathrm{TL}$ & 3 & 15,8 & 16 & 84,2 & & 6 & 31,6 & 13 & 68,4 & & 10 & 52,6 & 9 & 47,4 & \\
\hline $1500-1999 \mathrm{TL}$ & 8 & 22,9 & 27 & 77,1 & & 6 & 17,1 & 29 & 82,9 & & 26 & 74,3 & 9 & 25,7 & \\
\hline $\begin{array}{l}2000 \text { TLve } \\
\text { üzeri }\end{array}$ & 18 & 19,1 & 76 & 80,9 & & 21 & 22,3 & 73 & 77,7 & & 60 & 63,8 & 34 & 36,2 & \\
\hline Meslek & & & & & & & & & & & & & & & \\
\hline Ev hanımı & 2 & 25,0 & 6 & 75,0 & & 2 & 25,0 & 6 & 75,0 & & 4 & 50,0 & 4 & 50,0 & \\
\hline Öğrenci & 8 & 38,1 & 13 & 61,9 & $\chi^{2: 8,007}$ & 11 & 52,4 & 10 & 47,6 & & 13 & 61,9 & 8 & 38,1 & \\
\hline İşçi & 12 & 24,5 & 37 & 75,5 & p:0,091 & 8 & 15,7 & 43 & 84,3 & $\chi^{2}: 10,905$ & 36 & 73,5 & 13 & 26,5 & $\chi^{2}: 4,494$ \\
\hline Memur & 10 & 19,6 & 41 & 90,9 & & 12 & 27,3 & 32 & 72,7 & p:0,028* & 28 & 54,9 & 23 & 45,1 & $\mathrm{p}: 0,343$ \\
\hline $\begin{array}{l}\text { Serbest } \\
\text { meslek }\end{array}$ & & & & & & 44 & 25,4 & 129 & 74,6 & & 29 & 65,9 & 15 & 34,1 & \\
\hline
\end{tabular}

Satır yüzdesi alınmıştır. ${ }^{*} P<0,05$ 
Tablo 6: Demografik Değişkenlere Göre Akılcı İlaç Kullanım Özellikleri ve Gruplar Arası Farklılığı Gösteren Ki-Kare Analizi

\begin{tabular}{|c|c|c|c|c|c|c|c|c|c|c|c|c|c|c|c|}
\hline \multirow[b]{3}{*}{ Cinsiyet } & \multicolumn{5}{|c|}{$\begin{array}{l}\text { İlaç temini sırasında reçetede yazılandan farklı } \\
\text { olarak, eczacının önerdiği eşdeğer ilacı (farklı } \\
\text { firmaların aynı etken maddeli ilacı) kabul eder } \\
\text { misiniz? }\end{array}$} & \multicolumn{5}{|c|}{$\begin{array}{l}\text { Reçete ile ilaç alırken, reçetede yazan ilaç olup } \\
\text { olmadığını kontrol eder misiniz? }\end{array}$} & \multicolumn{5}{|c|}{$\begin{array}{l}\text { Hekime giderken daha önce kullanmış } \\
\text { olduğunuz ilaçlar ve varsa kronik } \\
\text { hastalıklarınıza ait raporlarınız hakkında } \\
\text { hekimi bilgilendirir misiniz? }\end{array}$} \\
\hline & \multicolumn{2}{|l|}{ Evet } & \multicolumn{2}{|c|}{ Hayır } & \multirow[t]{2}{*}{$\begin{array}{l}\text { Test ve p } \\
\text { değeri }\end{array}$} & \multicolumn{2}{|l|}{ Evet } & \multicolumn{2}{|c|}{ Hayır } & \multirow[t]{2}{*}{$\begin{array}{l}\text { Test ve p } \\
\text { değeri }\end{array}$} & \multicolumn{2}{|c|}{ Evet } & \multicolumn{2}{|c|}{ Hayır } & \multirow{2}{*}{$\begin{array}{l}\text { Test } \\
\text { ve p } \\
\text { değer } \\
\mathrm{i}\end{array}$} \\
\hline & Say1 & $\%$ & Sayl & $\%$ & & Sayl & $\%$ & Say & $\%$ & & Sayl & $\%$ & Sayl & $\%$ & \\
\hline Kadın & 17 & 32,7 & 35 & 67,3 & \multirow[b]{2}{*}{$\begin{array}{l}\chi^{2}: 9,209 \\
\mathbf{p}: \mathbf{0 , 0 0 2}\end{array}$} & 36 & 69,2 & 16 & 30,8 & \multirow[b]{2}{*}{$\begin{array}{l}\chi^{2}: 1,704 \\
\mathrm{p}: 0,192\end{array}$} & 41 & 78,8 & 11 & 21,2 & \multirow{2}{*}{$\begin{array}{l}\chi^{2}: 1,3 \\
53 \\
\text { p: } 0,2 \\
45\end{array}$} \\
\hline Erkek & 70 & 57,9 & 51 & 42,1 & & 95 & 78,5 & 26 & 21,5 & & 104 & 86,0 & 17 & 14,0 & \\
\hline \multicolumn{16}{|l|}{ Yaș } \\
\hline $\begin{array}{l}18-30 \text { yaş } \\
\text { arası }\end{array}$ & 21 & 31,8 & 45 & 68,2 & \multirow{4}{*}{$\begin{array}{l}\chi^{2}: 16,599 \\
\mathbf{p}: \mathbf{0 , 0 0 1}\end{array}$} & 47 & 71,2 & 19 & 28,8 & \multirow{4}{*}{$\begin{array}{l}\chi^{2}: 7,971 \\
\mathbf{p}: \mathbf{0 , 0 4 7 *}\end{array}$} & 56 & 84,8 & 10 & 15,2 & \multirow{4}{*}{$\begin{array}{l}\chi^{2}: 7,5 \\
52 \\
\text { p: } 0,0 \\
56\end{array}$} \\
\hline $\begin{array}{l}31-40 \text { yaş } \\
\text { arası }\end{array}$ & 38 & 66,7 & 19 & 33,3 & & 39 & 68,4 & 18 & 31,6 & & 52 & 91,2 & 5 & 8,8 & \\
\hline $\begin{array}{l}41-50 \text { yaş } \\
\text { arası }\end{array}$ & 20 & 60,6 & 13 & 39,4 & & 30 & 90,9 & 3 & 9,1 & & 26 & 78,8 & 7 & 21,2 & \\
\hline $\begin{array}{l}51-64 \text { yaș } \\
\text { arası }\end{array}$ & 8 & 47,1 & 9 & 52,9 & & 15 & 88,2 & 2 & 11,8 & & 11 & 64,7 & 6 & 35,3 & \\
\hline \multicolumn{16}{|l|}{$\begin{array}{l}\text { Eğitim } \\
\text { durumu }\end{array}$} \\
\hline İlköğretim & 8 & 38,1 & 13 & 61,9 & \multirow{4}{*}{$\begin{array}{l}\chi^{2}: 1,626 \\
\mathrm{p}: 0,654\end{array}$} & 17 & 81,0 & 4 & 19,0 & \multirow{4}{*}{$\begin{array}{l}\chi^{2}: 10,181 \\
\mathbf{p}: \mathbf{0 , 0 1 7}\end{array}$} & 11 & 52,4 & 10 & 47,6 & \multirow{4}{*}{$\begin{array}{l}\chi^{2}: 20,89 \\
0 \\
\mathbf{p}: \mathbf{0 , 0 0 0} \\
*\end{array}$} \\
\hline Lise & 29 & 50,9 & 28 & 49,1 & & 47 & 82,5 & 10 & 17,5 & & 54 & 94,7 & 3 & 5,3 & \\
\hline Lisans & 32 & 54,2 & 27 & 45,8 & & 47 & 79,7 & 12 & 20,3 & & 51 & 86,4 & 8 & 13,6 & \\
\hline $\begin{array}{l}\text { Yüksek } \\
\text { lisans/dok } \\
\text { tora }\end{array}$ & 18 & 50,0 & 18 & 50,0 & & 20 & 55,6 & 16 & 44,4 & & 29 & 80,6 & 7 & 19,4 & \\
\hline \multicolumn{16}{|l|}{$\begin{array}{l}\text { Gelir } \\
\text { seviyesi }\end{array}$} \\
\hline $0-499 \mathrm{TL}$ & 4 & 21,1 & 15 & 78,9 & \multirow{5}{*}{$\begin{array}{l}\chi^{2}: 12,435 \\
\mathbf{p}: \mathbf{0 , 0 1 4}\end{array}$} & 15 & 78,9 & 4 & 21,1 & \multirow{5}{*}{$\begin{array}{l}\chi^{2}: 1,355 \\
\mathrm{p}: 0,854\end{array}$} & 17 & 89,5 & 2 & 10,5 & \multirow{5}{*}{$\begin{array}{l}\chi^{2}: 14 \\
427 \\
\mathbf{p}: \mathbf{0 , 0} \\
\mathbf{0 6}\end{array}$} \\
\hline $\begin{array}{l}500-999 \\
\text { TL }\end{array}$ & 1 & 16,7 & 5 & 83,3 & & 5 & 83,3 & 1 & 16,7 & & 3 & 50,0 & 3 & 50,0 & \\
\hline $\begin{array}{l}1000- \\
1499 \mathrm{TL}\end{array}$ & 8 & 42,1 & 11 & 57,9 & & 16 & 84,2 & 3 & 15,8 & & 12 & 63,2 & 7 & 36,8 & \\
\hline $\begin{array}{l}1500- \\
1999 \mathrm{TL}\end{array}$ & 21 & 60,0 & 12 & 40,0 & & 26 & 74,3 & 9 & 25,7 & & 33 & 94,3 & 2 & 5,7 & \\
\hline $\begin{array}{l}2000 \mathrm{TL} \\
\text { ve üzeri }\end{array}$ & 53 & 56,4 & 41 & 43,6 & & 69 & 73,4 & 25 & 26,6 & & 80 & 85,1 & 14 & 14,9 & \\
\hline Meslek & & & & & & & & & & & & & & & \\
\hline Ev hanımı & 3 & 37,5 & 5 & 62,5 & & 5 & 62,5 & 3 & 37,5 & & 5 & 62,5 & 3 & 37,5 & \\
\hline Öğrenci & 4 & 19,0 & 17 & 81,0 & & 16 & 76,2 & 5 & 23,8 & & 17 & 81,0 & 4 & 19,0 & \\
\hline İșçi & 30 & 61,2 & 19 & 38,8 & $\chi^{2}: 12,964$ & 39 & 79,6 & 10 & 20,4 & $\chi^{2}: 1,393$ & 43 & 87,8 & 6 & 12,2 & 58 \\
\hline Memur & 30 & 58,8 & 21 & 41,2 & p:0,011* & 39 & 76,5 & 12 & 23,5 & $\mathrm{p}: 0,845$ & 42 & 82,4 & 9 & 17,6 & $\mathrm{p}: 0,4$ \\
\hline $\begin{array}{l}\text { Serbest } \\
\text { meslek }\end{array}$ & 20 & 45,5 & 24 & 54,5 & & 32 & 72,7 & 12 & 27,3 & & 38 & 86,4 & 6 & 13,6 & 54 \\
\hline
\end{tabular}

Satır yüzdesi alınmıştır. ${ }^{*} P<0,05$

Tablo 7: Katılımcıların Akılcı İlaç Kullanımına İlişkin Sorulara Verdikleri Yanıtların Dağılımı

\begin{tabular}{|l|l|l|}
\hline Ağrı kesici ihtiyacınız olduğunda ilacı nasıl temin edersiniz? & $\mathbf{N}$ & $\mathbf{\%}$ \\
\hline Reçete ile eczaneden & 84 & 48,6 \\
\hline Reçetesiz eczaneden & 74 & 42,8 \\
\hline Komşudan, tanıdıktan & 15 & 8,7 \\
\hline $\begin{array}{l}\text { Komşularınız ve/veya yakınlarınızın tavsiyesi ile ilaç kullanır mısınız ya da } \\
\text { doktorunuzdan reçete etmesini ister misiniz? }\end{array}$ & $\mathbf{N}$ & $\mathbf{\%}$ \\
\hline Evet & 31 & 17,9 \\
\hline Hayır & 142 & 82,1 \\
\hline Hastalık durumunda veya herhangi bir ağrı durumunda ne yaparsınız? & $\mathbf{N}$ & $\mathbf{\%}$ \\
\hline Hekime danışırım & 154 & 89,0 \\
\hline Eczacıya danışırım & 13 & 7,5 \\
\hline Bitkisel tedavi yöntemlerini denerim. & 6 & 3,5 \\
\hline Aldığınız ilaçların (prospektüs) kutu içerisindeki formu okur musunuz? & $\mathbf{N}$ & $\mathbf{\%}$ \\
\hline Evet & 153 & 88,4 \\
\hline Hayır & 20 & 11,6 \\
\hline
\end{tabular}




\begin{tabular}{|c|c|c|}
\hline İlacın yan etkileri ile karşılaşırsanız nasıl davranırsınız? & $\mathrm{N}$ & $\%$ \\
\hline Hekime bașvururum. & 155 & 89,6 \\
\hline Eczaciya bașvururum. & 7 & 4,0 \\
\hline $\begin{array}{l}\text { Eczacınız, aldığınız ilacın nasıl kullanılacağı konusunda bilgi verip doğru } \\
\text { anlașıldığına emin olana kadar anlatıyor mu? }\end{array}$ & $\mathbf{N}$ & $\%$ \\
\hline Evet & 159 & 91,9 \\
\hline Hayır & 14 & 8,1 \\
\hline Aile bireylerinin bir tedavi sonrası arta kalan ilaçlarını ne yaparsınız? & $\mathbf{N}$ & $\%$ \\
\hline Gerektiği zaman kullanılmak üzere saklarım & 73 & 42,2 \\
\hline Sağlık kurulușlarına veririm & 32 & 18,5 \\
\hline Eczaneye veririm & 26 & 15,0 \\
\hline Cöpe atarım & 42 & 24,3 \\
\hline İlacin son kullanma tarihini kontrol eder misiniz? & $\mathbf{N}$ & $\%$ \\
\hline Daima & 111 & 64,2 \\
\hline Genellikle & 42 & 24,3 \\
\hline Bazen & 20 & 11,6 \\
\hline Hekimin vermiş olduğu ilaçları ne șekilde kullanırsınız? & $\mathbf{N}$ & $\%$ \\
\hline İlaç bitene kadar kullanırım. & 44 & 25,4 \\
\hline Şikâyetim geçene kadar kullanırım. & 60 & 34,7 \\
\hline Hekim veya eczacının önerdiği süre kullanırım. & 69 & 39,9 \\
\hline $\begin{array}{l}\text { Üzerinde saklama koşulları ile ilgili herhangi bir uyarı bulunmayan ilaçları nerede } \\
\text { saklıyorsunuz? }\end{array}$ & $\mathbf{N}$ & $\%$ \\
\hline Buzdolabında & 66 & 38,2 \\
\hline Oda sıcaklı̆̆ında, serin ve kuru bir yerde & 107 & 61,8 \\
\hline Evinizde hiç kullanılmamış veya yarım kalmış ortalama kaç kutu ilaç vardır? & $\mathbf{N}$ & $\%$ \\
\hline Hiç yok & 46 & 26,6 \\
\hline $1-5$ arası & 73 & 42,2 \\
\hline 6-10 arası & 22 & 12,7 \\
\hline 10 'dan fazla & 32 & 18,5 \\
\hline $\begin{array}{l}\text { Hekime giderken daha önce kullanmış olduğunuz ilaçlar ve varsa kronik } \\
\text { hastalıklarınıza ait raporlarınız hakkında hekimi bilgilendirir misiniz? }\end{array}$ & $\mathbf{N}$ & $\%$ \\
\hline Evet & 163 & 94,2 \\
\hline Hayır & 10 & 5,8 \\
\hline $\begin{array}{l}\text { Basında (televizyon, radyo, gazete vb.) reklamı yapılan ürünleri tedavi amacıyla } \\
\text { kullanır mısınız? }\end{array}$ & $\mathbf{N}$ & $\%$ \\
\hline Hekime danıșarak kullanırım & 20 & 11,6 \\
\hline Eczacıya danıșarak kullanırım. & 14 & 8,1 \\
\hline Kullanmam & 139 & 80,3 \\
\hline Benzer șikâyetleri olan tanıdıklarınıza ilaç tavsiyesinde bulunur musunuz? & $\mathbf{N}$ & $\%$ \\
\hline Evet & 44 & 25,4 \\
\hline Hayır & 129 & 74,6 \\
\hline
\end{tabular}

Tablo 7'de katılımcıların akılcı ilaç kullanımına ilişkin sorulara verdikleri yanıtların dağılımı gösterilmiştir. Ağrı kesici ihtiyaçları olduğunda katılımcıların \%48,6'sı reçete ile eczaneden aldığını belirtirken, \%42,8'i eczaneden reçetesiz aldığını belirmiștir. Yapıcı vd. (2011) tarafından yapılan çalışmada ise katılımcıların \% 31,3'ünün reçetesiz olarak ilaç kullandıkları belirlenmiştir. Komşularının veya yakınlarının tavsiyesi ile ilaç kullanma durumlarında katılımcıların \%82,1'i tavsiye ile ilaç kullanmadıklarını ifade etmişlerdir. Bu sonuç ise hekim önerisi olmadan ilaç kullanımı konusunda bireylerin önemli ölçüde bilinçli davrandıklarını göstermektedir. Özkan, Özbay, Aksaka, İlhan, \& Aycan (2005) tarafından yapılan çalışmada tavsiye ile ilaç kullanma oranı \%25,6 olarak bulunurken, Yılmaz (2011) tarafından gerçekleștirilen çalışmada ise, katılımcıların \%24,7'si bașkalarına iyi gelen ilacı kullandıklarını ifade etmişlerdir.

Tablo 7'den görülebileceği gibi hastalık veya herhangi bir ağrı durumunda katılımcıların \%89'u hekime danışmaktadırlar. Yılmaz, Yılmaz, Karaca, Uçar, \& Yüce'nin (2008) çalışmasında ise katılımcıların herhangi bir ağrı durumunda \%32,1'inin alternatif tıp yöntemlerini kullandığı belirlenmiştir. Özkan vd., (2005) çalışmasında katılımcıların 
\%69.5'i herhangi bir hastalık halinde hekime başvurdukları belirlenmiștir. Yine Tablo 7'de katılımcların \% 88,4'ünün aldıkları ilaçların kutu içerisindeki bilgi formunu (prospektüs) okudukları belirlenmiștir. Bu oran Karakurt, Hacıhasanoğlu, Yıldırım, \& Sağlam'ın (2010) yaptıkları çalışmada \%83,6 iken, Kaya vd., (2015)'nin yaptığı çalışmada ise \%90,6 dır. Katılımcıların \%89,4'ünün kullandıkları ilacın yan etkileri görüldüğünde hekime başvurdukları tespit edilmiştir. Esin, Bulduk, Dural, Şenolan, \& Temel'in (2007) yaptıkları çalışmada bu oran \%70 iken, Yılmaz vd., (2008)'nin yaptığı çalışmada ise $\% 54,2$ 'dir.

Tablo 7'de görülebileceği gibi katılımcıların \% 91,9'u eczaneden aldıkları ilaçlar hakkında yeterince bilgi verilip, anlaşılana kadar bilgilendirme yapıldığı bulgusuna ulaşılmıștır. Demirel Duran (2014) hastaların akılcı ilaç kullanımına ilișkin tutumlarını belirleme çalıșmasında katılımcılar \%62,8'inin ilaçlar hakkında bilgilendirme yapıldığını belirtmişlerdir. Bireylerin aile bireylerinde bir tedavi sonrası arta kalan ilaçları \%42,2'sinin gerektiği zaman kullanılmak üzere sakladıklarını ifade etmişlerdir (Tablo 7). Demirel Duran (2014) yaptığı çalıșmada katılımcıların \%50'si kullanılmayan ilaçları sakladıklarını belirtmişlerdir. İlhan, Aydemir, Çakır, \& Aycan'ın (2014) akılcı olmayan ilaç kullanımı davranışlarını belirleme çalışmasında bireylerin \%60,3'ünün kullanılmayan ilaçları buzdolabında sakladıkları görülmüştür.

Katılımcıların \%64,2'si aldıkları ilaçların son kullanma tarihlerine dikkat ettikleri Tablo 7'de görülmektedir. Yapıcı vd., (2011) yapmış olduğu çalışmada bireylerin \% 79,3'ünün aldıkları ilaçların son kullanma tarihini okudukları görülmüştür. Bireylerde yaygın görülen davranışlardan biride ilaç tedavisi sırasında semptomların geçmesi nedeniyle ilaç tedavilerini yarıda kesmeleri bireylere enfeksiyon veya rahatsızlığın tekrar etmesi ile sonuçlanabilmektedir. Tablo 7'de katılımcıların \%39,9'u hekimin vermiş olduğu ilacı hekim veya eczane personelinin önerdiği süre boyunca kullandıklarını belirtmişlerdir. Kaya vd., (2015) yaptıkları çalışmada katılımcıların \%62,2'sinin, Özçelikay'ın (2001) çalışmasında \%23,9'unun, Yılmaz vd., (2008)'nin çalışmasında \%28,8'inde, Uğrak, Teke, Cihangiroğlu, \& Uzuntarla'nın (2015) çalışmasında ise \%16,5'inin yakınmaları geçince ilaç kullanımını bıraktıkları bulgulanmıștır.

Tablo 7'de bireylerin ilaçları saklama ortamları olarak \%61,8'i oda sıcaklığında kuru bir yerde saklanması gerektiğini belirtirken, \% 38,2'si buzdolabında ilaçları sakladıklarını belirtmişlerdir. Göçgeldi vd., (2009)'nin çalışmasında katılımcıların \% 42,9'u aldıkları ilaçları ecza dolabında veya özel bir çekmecede sakladıkları bulgusuna ulaşmışlardır. De Bolle, Mehuys, Adriaens, Remon, \& Van Bortel (2008) yapmış oldukları çalışmada, evlerdeki mevcut ilaçların yaklaşık üçte birinin uygunsuz şartlarda saklandığını saptamıșlardır.

Katılımcıların \% 42,2'si evlerinde hiç kullanılmamıș veya yarım kalmıș 1-5 kutu arası ilaç olduğunu, \%26,6'sının ise evlerinde hiç kullanılmamış veya yarım kalmış ilacın bulunmadığı tablo 7'de bulgulanmıştır. Göçgeldi vd.'nin (2009) çalışmasında bu oranının \%38,7 olduğu, Uğrak vd.'nin (2015) çalışmasında ise bireylerin \%30,7'sinin evlerinde yarım kalmış ya da hiç kullanılmamış ilaç olmadığı bulunmuştur.

Tablo 7'de katılımcıların \% 94,2'si hekime gittiğinde önceden kullandığı ilaç var ise ya da herhangi bir kronik rahatsızlığı varsa hekimi bilgilendirdikleri görülmektedir. Uğrak vd., (2015) çalışmasında ise katılımcıların \%93,4'ünün bilgilendirme yaptıkları belirlenmiștir. Bu araștırmada basın yoluyla reklamı yapılan ürünleri tedavi maksatlı olarak kullanım konusunda katılımcıların \%80,3'ünün bunları kullanmadığı, \%11,6'sının ise hekime danışarak kullandığı belirlenirken, Uğrak vd., (2015) çalışmasında katılımcıların \%22,3'ünün bu ürünleri hekime danışarak kullandığı bulunmuştur. Katılımcıların \% 74,6'sı benzer şikâyetleri olan tanıdıklarına ilaç tavsiyesinde bulunmadıklarını belirtirken, Demirel Duran (2014) çalıșmasında bireylerin \%56,4'ünün başkalarına ilaç tavsiyesinde bulunmadıkları belirlenmiștir. 


\section{Sonuç}

$\mathrm{Bu}$ araştırmada katılımcıların akılcı ilaç kullanımı konusunda bilgi düzey ve davranışlarını belirlemek amacıyla yapılmıștır. Akılcı ilaç kullanımında olumlu gelişmelerin sağlanabilmesi öncelikle mevcut durumun ortaya konmasını gerektirmektedir. Akılcı ilaç kullanımın en önemli ayaklarından birisini olușturan bireylerin bu konudaki bilgi düzeyleri ve davranışlarının belirlenmesi bu alanda atılacak adımlar için önemli bir başlangıç noktası olacaktır (Karataş, Dinler, Erdoğdu, Ertuğ ve Seydaoğlu, 2012, s. 6).

İstatistiksel açıdan anlamlı sonuçlara bakıldığında toplumda en yaygın kullanılan ilaçlardan olduğu söylenebilecek ağrı kesici ihtiyaçları olduğunda erkek katılımcıların \%91,1'i ve kadın katılımcıların \%82,7'sinin hekime danıştıkları belirlenmiștir. Katılımcılarının aldıkları ilaçların son kullanma tarihini kontrol etme oranın erkeklerde $\% 66,9$ ve kadınlarda \%57,7'dir. Bireylerin evde bulundurdukları ilaçları tekrar kullanmak istediklerinde erkek katılımcıların \%41,3'ü hekimden bilgi aldıklarını, \%28,1'i ise eczane görevlisinden bilgi aldıklarını belirtirken, kadın katılımcıların \%32,7'sinin ise hekimden bilgi aldıkları görülmüştür. Eğitim durumu dikkate alındığında yükseköğretim mezunlarının \%39'u ve yüksek lisans/doktora mezunlarının \%41,9'u hekimden bilgi aldıklarını, lise mezunlarının \%40,4'ü eczacı personelinden bilgi aldıklarını, ilköğretim mezunlarının \% 57,1'inin hekimden bilgi aldıkları bulgusuna ulaşılmıștır. Bireylerin evlerinde hiç kullanılmamış veya yarım kalmış olan ilaç kutu miktarında erkek bireylerin \%47,1'i ile kadın bireylerin \%30,8'i 1-5 kutu arası ilaç bulunduğunu belirtmiştir.

Katılımcıların besin veya ilaç alerjisi olmaları durumunda hekim veya sağlık personelini bilgilendirme oranları hayli yüksek bulunmuştur. Katılımcıların 51-64 yaș arası grubun tamamı, 41-50 yaş arasının \%90,9'u, 31-40 yaş arası grubun \%98,2'si, 18-30 yaş arası grubun ise \%84,8'i besin veya ilaç alerjisi var ise; muayene sırasında hekimi ve ilgili sağlık personelini bilgilendirmektedirler. Aynı konuda yükseköğretim mezunlarının \%96,6'sının, ilköğretim mezunlarının \%95,2'sinin, lise mezunlarının \%93'ünün, yüksek lisans/doktora mezunlarının ise 80,4'ünün besin veya ilaç alerjisi konusunda hekim ve ilgili sağlık personelini bilgilendirdikleri bulgusuna ulașlmıştır.

Erkek katılımcıların \%78,5'inin, kadın katılımcıların \%69,2'sinin reçetede yazan ilaçları kontrol etmektedirler. Hekimi daha önce kullanmış oldukları ilaçlar hakkında veya kronik rahatsızlıkları hakkında bilgilendirme konusunda erkek bireylerin \%86'sının, kadın bireylerin ise \%78,8'inin bilgilendirme yaptıkları görülmektedir. Ağrı kesici ihtiyaçları olduğunda katılımcıların \%48,6'sı reçete ile eczaneden aldığını belirtirken, \%42,8'i eczaneden reçetesiz aldığını belirtmiștir. Komşularının veya yakınlarının tavsiyesi ile ilaç kullanma durumlarında katılımcıların \%82,1'i tavsiye ile ilaç kullanmadıklarını ifade etmişlerdir. Bu sonuç ise hekim önerisi olmadan ilaç kullanımı konusunda bireylerin önemli ölçüde bilinçli davrandıklarını göstermektedir. Özkan vd., (2005) tarafından yapılan çalışmada tavsiye ile ilaç kullanma oranı \%25,6 olarak bulunurken, Yılmaz (2011) tarafından gerçekleștirilen çalışmada ise, katılımcıların \%24,7'si başkalarına iyi gelen ilacı kullandıklarını ifade etmişlerdir.

Hastalık veya herhangi bir ağrı durumunda katılımclların \%89'u hekime danışmaktadırlar. Yine bireylerin \%88,4'ünün aldıkları ilaçların kutu içerisindeki bilgi formunu (prospektüs) okudukları belirlenmiştir. Katılımcıların \%91,9'u eczaneden aldıkları ilaçlar hakkında yeterince bilgi verilip, anlașılana kadar bilgilendirme yapıldığı bulgusuna ulaşılmıștır. Katılımcıların \%64,2'si aldıkları ilaçların son kullanma tarihlerine dikkat etmekte ve \%39,9'u hekimin vermiş olduğu ilacı hekim veya eczane personelinin önerdiği süre boyunca kullanmaktadırlar. Katılımcıların büyük çoğunluğu (\%80) basında 
(TV., radyo ve gazete vb. gibi) tedavi amaçlı reklamı yapılan ürünleri kullanmazken, \%11'lik bir kısım doktora danışarak kullanmaktadırlar.

$\mathrm{Bu}$ çalışmada genel olarak bireylerin ilaç kullanımı konusunda bilgi düzey ve alışkanlıklarının yüksek çıkması ve bu bulgunun literatür ile de uyumlu olması Sağlık Bakanlığı ve ilgili kuruluşların ilaç kullanıcılarını bilinçlendirme çabalarının da başarılı olduğunun bir göstergesidir denilebilir. Bununla beraber iyileștirme yapılabilecek bir potansiyelin varlığı da göz ardı edilmemelidir. Çünkü ilaç gibi hem sağlık açısından hem de ekonomik kaynakların etkin kullanılması göz önünde bulundurulduğunda çok küçük iyileştirmelerin dahi sonuç itibarıyla önemli kazanımlar sağlayabileceği vurgulanmalıdır. Akılcı ilaç kullanımı ilaç stoklarında dengeyi, ilaç ekonomisindeki kontrolü sağlama açısında gelişmiş ve gelişmekte olan ülkeler açısından üzerinde durulan önemli bir kavramdır. Çünkü bu ülkeler ilaç konusunda önemli ölçüde dıșa bağımlıdırlar. Türkiye'de gelişmekte olan ülkeler arasında yer aldığına göre bu konu da yapılan çalışmalar incelendiğinde bireylerin akılcı ilaç kullanım noktasında bilgi sahibi olduğu fakat yeteri kadar istenilen düzeyde olmadığı görülmüştür.

$\mathrm{Bu}$ çalıșmada elde edilen verilere göre bireylerin akılcı ilaç kullanımlarında bilgi düzeylerinin yüksek olduğu ifade edilebilir. Mevcut bilgi düzeyinin korunarak daha ileri seviyelere taşınması için broşürler, bilgilendirici reklamlar, halk eğitim merkezlerinde konuyla ilgili eğitimler, seminerler yapılması düşünülebilir. Özellikle gereksiz ilaç kullanımı ve çöpe atılan ilaçlar noktasında topluma ilaçlar ile ilgili bilgiler verilmeli ve bunların ekonomiye ve çevreye karşı etkileri konusunda toplum yeterince bilinçlendirilmelidir. Bu konuyla ilgili en başta sorumluluk ilgili yöneticilere düşmekle beraber toplumumuzu oluşturan tüm bireylere bu konuda görev düşmektedir. Bu çalışma ile ulaşılan bulguların tüm Türkiye'ye genellenmesi elbette ki mümkün değildir. Fakat bu araştırma Türkiye'deki büyük resmin daha iyi anlaşılmasına bir nebze de olsa katkıda bulunmaktadır. Bu çalıșmanın literatür bilgisi ve elde edilen verilerle alana katkı sağlayacağı düşünülmektedir.

\section{KAYNAKÇA}

AFRIYIE, D.K. \& TETTEH, R. (2014). A description of the pattern of rational drug use in Ghana Police Hospital. International Journal of Pharmacy and Pharmacology, 3(1), 143-148.

AKICI, A. \& KALAÇA, S. (2013). Topluma yönelik akılcı ilaç kullanımı. Ankara: Sosyal Güvenlik Kurumu Yayınları.

AKSOY, M., ALKAN, A. \& İȘLİ, F. (2015). Sağlık Bakanlığı'nın akılcı ilaç kullanımı yaygınlaștırma faaliyetleri. Türkiye Klinikleri J Pharmacol-Special Topics, 3(1), 19-26. ÇALIKOĞLU, O. (2006). Erzurum il merkezinde çalışan pratisyen hekimler ile 20 yaş ve üzeri kişilerin akılcı ilaç kullanım boyutları ve etkileyen faktörler. T.C. Atatürk Üniversitesi Tıp Fakültesi Halk Sağlığı Anabilim Dalı Uzmanlık Tezi. Erzurum.

DE BOLLE, L., MEHUYS, E., ADRIAENS, E., REMON, J.P. \& VAN BORTEL, L. (2008).

Home medication cabinets and self-medication: a source of potential health threats? Ann Pharmacother, 42(4), 572-579.

DURAN DEMIREL, A. (2014). Antalya Eğitim ve Araştırma Hastanesi'nde sağlık çalışanları ile tedavi alan hastaların akılcı ilaç kullanımına ilişkin tutumları. Yayınlanmıș Yüksek Lisans Tezi. Beykent Üniversitesi Sosyal Bilimler Üniversitesi. İstanbul.

EKENLER, Ş. \& KOÇOĞLU, D. (2016). Bireylerin akılcı ilaç kullanımıyla ilgili bilgi ve uygulamaları, Hacettepe Üniversitesi Hemşirelik Fakültesi Dergisi, 3(3), 44-55.

ESIN, M. N., BULDUK, S., DURAL, Ç., ŞENOLAN, G. \& TEMEL, E. (2007). Erişkin bireylerin ilaç kullanma ile ilgili davranışları. İ. Ü. F. N. Hem. Dergisi, 15(60), 139-145. 
GÖÇGELDİ, E., UÇAR, M., AÇIKEL, C.H., TÜRKER, T., HASDE, M. \& ATAÇ, A. (2009). Evlerde artık ilaç bulunma sıklığı ve ilişkili faktörlerin araştırılması. TAF Prev Med Bull, 8(2): 113-118.

GÜNDOĞAR SOYKUT, H. \& KARTAL, E.S. (2017). Üniversite öğrencilerinin akılcı ilaç kullanımı hakkındaki görüşleri. Bartın Üniversitesi Eğitim Araştırmaları Dergisi, 1(1), 25-34.

İLHAN, N.M., AYDEMİR, Ö., ÇAKIR, M. \& AYCAN. S. (2014). Akılcı olmayan ilaç kullanım davranışları: Ankara'da üç ilçe örneği. Turk J Public Health, 12(3), 188-200.

KARAKURT, P., HACIHASANOĞLU, R., YILDIRIM, A. \& SAĞLAM, R. (2010). Üniversite öğrencilerinde ilaç kullanımı. TAF Prev Med Bull, 9(5), 505-512.

KARATAŞ, Y. , DINLER, B., ERDOĞDU, T., ERTUĞ, P. \& SEYDAOĞLU, G. (2012) .Çukurova Üniversitesi Tıp Fakültesi Balcalı Hastanesi'ne Bașvuran Hasta ve Hasta Yakınlarının İlaç Kullanım Alışkanlıklarının Belirlenmesi. Çukurova Üniversitesi Tıp Fakültesi Dergisi, 37(1), 1-8.

KAYA, H., TURAN, N., KESKIN, Ö., TENCERE, Z., UZUN, E., DEMIR, G. \& YILMAZ, T. (2015). Üniversite öğrencilerinin akılcı ilaç kullanma davranışları. Anadolu Hemşirelik ve Sağlık Bilimleri Dergisi, 18 (1), 35-42.

ÖZÇELIKKAY, G. (2001). Akılcı ilaç kullanımı üzerinde bir pilot çalışma. Ankara Eczacılık Fakültesi Dergisi, 30(2), 9-18.

ÖZKAN, S., ÖZBAY, O.D., AKSAKA, F.N., İLHAN, M.N. \& AYCAN, S. (2005). Bir üniversite hastanesine başvuran hastaların hasta olduklarındaki tutumları ve ilaç kullanım alıșkanlıkları. Türk Silahlı Kuvvetleri Koruyucu Hekim Bul, 4(5), 223-37.

SÜRMELIOĞLU, N., KIROĞLU, O., ERDOĞDU, T. \& KARATAȘ, Y. (2015). Akılcı olmayan ilaç kullanımını önlemeye yönelik tedbirler. Arşiv Kaynak Tarama Dergisi, 24(4), 452-462.

TOPRAK, S. (2013). Akılcı ilaç kullanımı. Göğüs Kalp Damar Anestezi ve Yoğun Bakım Derneği 19. Ulusal Kongresi. 16-19 Mayıs 2013. Karadeniz Teknik Üniversitesi, Trabzon.

UĞRAK, U., TEKE, A., CIHANGIROĞLU, N. \& UZUNTARLA, Y. ( 2015). Kardiyoloji kliniğinde yatan hastaların akılcı ilaç kullanımı konusunda tutumları. TAF Prev Med Bull, 14(2), 137-144.

USKUN, E., USKUN, S.B., ÖZTÜRK, M. \& KIŞi̇iOĞLU, A.N. (2004). Sağlık ocağına başvuru öncesi ilaç kullanımı. Sürekli Tıp Eğitimi Dergisi, 13(12), 451-54.

WHO. (2011). Promoting Rational Use of Medicines.

WHO. (1997). Guide to good prescribing: A practical manual.

WHO. (1987). The Rational use of drugs: report of the conference of experts, Nairobi. 25-29 November 1985: World Health Organization.

YAPICI, G., BALIKÇI, S. \& UĞUR, Ö. (2011). Birinci basamak sağlık kuruluşuna başvuranların ilaç kullanımı konusunda tutum ve davranışları. Dicle Tıp Dergisi, 38(4), 458-465.

YILMAZ, E., YILMAZ, E., KARACA, F., UÇAR, S. \& YÜCE, T. (2008). Sağlık yüksekokulu öğrencilerinin ilaç kullanma durumlarının incelenmesi. Fırat Sağllk Hizmetleri Dergisi, 3(8), 69-83.

YILMAZ, M., GÜLER, N., GÜLER, G. \& KOCATAȘ, S. (2011). Bir Grup Kadının İlaç Kullanımı İle İlgili Bazı Davranışları: Akılcı Mı?. Cumhuriyet Tıp Dergisi, 33, 266-277.

YILMAZ, M., KIRBIYIKOĞLU İLTUŞ, F., ARIÇ, Z. \& KURŞUN, B. (2014). Bir Diş Hekimliği Fakültesi Hastanesi'ne Başvuran Bireylerin Akılcı Kullanımlarının Belirlenmesi. Erciyes Üniversitesi Sağlık Bilimleri Fakültesi Dergisi, 2(1), 39-47. 


\section{Summary}

Rational drug use has become one of the increasingly important issues of health today. rational drug use, one of the issues of concern to developed countries in Turkey comes at the beginning on the issues that need to be considered carefully by researchers in recent years. Rational drug use is the process of planning, conducting, and monitoring the outcomes of delivering drugs safely, economically and effectively in the treatment of the individual. The rational use of medication is the practice of the recommended treatment for the individual in the direction of the physician. Applications other than rational drug use are expressed as non-rational drug use. It can be shown as an example of rational drug use where individuals seek treatment on their own, without the physician's recommendation, the drug they use leads to adverse outcomes, the use of scarce resources inefficiently, the use of non-prescription drugs by individuals, the use of medicines by the physician as recommended, The main focus of this study is to examine the rational drug use knowledge of individuals. The research was carried out on patients who came to pharmacies in order to take medicine in Kahramanmaras Göksun province. T.C. The "Rational Drug Use" scale established by the Ministry of Health was used. Additional questions have been added by researchers to the rational use of drugs by the population. In the scope of the research, 173 participants were reached. Participants participating in the research were informed through an individual interview and their participation was provided on the basis of volunteerism by taking the residence of the individuals. The data were collected by interviewing the patients who came to the pharmacy. SPSS 21 package program was used for the evaluation of the data and chi-square analysis methods were used by the calculation of number-percentage. When the results of the research were examined, it was found that there was a meaningful difference between individuals' availability of pain reliever and their sex $(p<0,05) .49 .6 \%$ of male individuals and $46.2 \%$ of female subjects provided prescription medication from the pharmacy when pain relievers were needed. When the results of research on what individuals do in their disease state are examined, it is detected that $91.8 \%$ of male participants and $82.7 \%$ of female participants express consent to medication in disease states. It was determined that there was a significant difference between the status of controlling the expiration date of the drug and the sex of the individual $(p<0,05) .66 .9 \%$ of male subjects and $57.7 \%$ of female subjects were found to always check the expiry date of the drug they received. In the pharmacy where the study was conducted, a large majority of the participants were seen to have been told by the pharmacy officer until they were confident that the drug they received was safe to use and understood. When this ratio distribution was examined, 95\% of male participants and $84.6 \%$ of female participants answered positively in this direction. It was determined that there was a meaningful difference between the individuals who participated in the research and those who had similar complaints with their ages $(p<0,05)$. When age groups are examined; It was determined that $90.9 \%$ of the 41-50 age group did not have drug recommendation and 9,1\% of the same group had drug recommendation. 94.2\% of the participants were informed about the medicines or the chronic diseases that the participants had used before going to the clinic. As a result of the research, it can be stated that the rational drug use levels of the individuals are high in the direction of the data obtained. This result was found to be compatible with the literature. Compared with studies conducted in the past years, it can be said that rational drug use levels of individuals are increased but not yet reached the desired level. Despite this, the fact that the level of rational drug use of individuals has increased compared to previous years can be expressed as a positive indicator of the Ministry of Health's work in this area. It is proposed that the results of this study and the predictions will contribute to the field in the light and that the wider masses are made with a higher participant level. 